\title{
A CGE Simulation Of A Flat Tax As A Possibility For Tax Reform In South Africa
}

Lumengo Bonga-Bonga, University of Johannesburg, South Africa Martin Perold, University of Johannesburg, South Africa

\begin{abstract}
During recent years, there has been widespread interest in South Africa for the so-called "flat tax" systems that appear to have been implemented successfully in Eastern Europe. This paper applied a CGE modelling technique to compare the performance of the South African economy in case alternative tax systems, namely the progressive and the flat tax systems, are applied. The counterfactual situation whose effects are tested in this paper is a 10\% decrease in the VAT rate consistent with some popular call for the reduction of the degree of the regressiveness of VAT. The key performances of the South African economy are assessed in terms of economic growth, the welfare of households, equity and employment. On the basis of this empirical investigation the flat tax has a slight edge over the current progressive system.
\end{abstract}

Keywords: Progressive Tax; Flat Tax; Computable General Equilibrium

\section{INTRODUCTION}

C n recent times, there has been much interest in the so-called "flat tax" as a policy alternative to progressive taxation. The key feature of a flat tax is that there is a single tax rate on all personal income above a certain exemption level (Keen, Kim and Varsano, 2006). Supporters of flat tax systems claim that it would have significant advantages over progressive taxation, and several flat tax models have been proposed (Hall and Rabuska, 1995). Furthermore, thirteen countries have, so far, implemented a flat tax with a great deal of success (for a detailed review of the experiences of these countries, see Grecu, 2004).

The main advantages of a flat tax are twofold: firstly, it is much simpler than progressive taxation, leading its proponents to claim that tax returns under a flat tax could be completed on the back of a postcard (Hall and Rabushka, 1995; Forbes, 2005). A simpler tax system would save taxpayers time and money, and, therefore, reduce compliance costs and improve administrative efficiency.

Secondly, a flat tax is predicted to stimulate economic growth through its effects on labour supply and incentives to save and invest (Hall and Rabushka, 1995; Armey, 1996; Forbes, 2005). Because the marginal tax rate on all income above a given exemption level would be the same under a flat tax, the familiar substitution effect of a tax would be eliminated. As a result, the flat tax would improve incentives to work, because there would be no distortions arising from a high marginal rate.

On the other hand, economists generally justify progressive taxation on the grounds that it is more equitable than proportional taxation - it is claimed that most of the tax burden ought to be placed on the highest income earners, as the confiscation of a certain amount of income represents a smaller sacrifice on their part than the loss of the same amount of income by a low-income earner (Blum and Kalven, 1953). Thus, even if a flat tax would achieve the goals of simplicity, administrative efficiency and economic growth, it fails on redistributive grounds, as a disproportionate percentage of the tax burden is borne by those with low incomes. However, it may nevertheless be justified to adopt a flat tax, provided the positive effects outweigh the disadvantages.

In this paper, we investigate the possibility of implementing a version of the flat tax in South Africa using the computerised general equilibrium (hereafter abbreviated as CGE) technique. This will be done by comparing the 
effect of an economic shock (that is, a 10\% decrease in the VAT rate) on both the current, progressive system in South Africa and a hypothetical flat tax model that will be simulated using the CGE approach.

The paper begins with section 2 that provides a brief discussion of the most important justifications for adopting a progressive tax and how they may be criticised, as well as an outline of the arguments for a flat tax. Section 3 provides information on the tax reforms undergone in South Africa after the change to a democratic dispensation. Section 3 presents the data and the CGE methodology for the analysis. Section 4 discusses the simulation used in the study. Section 5 interprets the results of the simulations and section 6 concludes the study.

\section{THE CHOICE BETWEEN PROGRESSIVE AND FLAT TAXATION}

In their detailed review of the traditional arguments for progressive taxation, Blum and Kalven (1953) divide them into four main categories, namely benefit theory, the argument from stability, sacrifice theories and the equality argument. This section will provide a brief overview of each of these arguments, showing that they are not ultimately convincing. Following this discussion, the three types of arguments for the flat tax - namely, political responsibility, simplicity and economic incentives (as identified by Blum and Kalven, 1953) - will be considered.

\subsection{Arguments For Progressive Taxation}

The first argument for progressive taxation comes from benefit theory, which states that taxpayers ought to pay taxes in proportion to the benefits they receive from the government. Hobbes (1651: 184) provides one of the first statements of the benefit principle, saying that the equal imposition of a tax depends "not on the [e]quality of riches but on the [e]quality of the debt, that every man oweth to the Commonwealth for his defence".

This leads us to the justification of progressive taxation. Since those with the highest incomes have the most to lose if the state does not protect them, they ought to contribute the most in taxes. Tax, according to this theory, is a type of insurance premium paid to the state for the protection of one's property and earning power - as the rich own more, their premiums should be the highest. Furthermore, wealthy entrepreneurs require the labour of skilled workers and a good infrastructure for their profits. As a result, they depend on the state to provide education for the workforce and to maintain and upgrade infrastructure; therefore, they ought to pay more for these benefits than other citizens who depend on the government in a lesser degree. In this way, "every man payeth equally for what he useth" (Hobbes, 1651: 184).

This principle has been questioned extensively, however. Mill (1852) provides an important criticism, claiming that all citizens benefit equally from government spending in most cases. For instance, everyone in the country benefits equally from government spending on national defence, as the entire nation is protected by the army. If citizens receive equal benefits, they ought to pay equally - in this way, the benefit principle actually leads to proportional taxation. Furthermore, since the lowest income earners are often those who are least able to afford services such as private health care and education, the benefit principle might even be said to support regressive taxation, since the poor will make the greatest use of government services and should, therefore, pay the most (Mill, 1863; Seligman, 1908). Thus, as Seligman (1908) notes, "this defence of progressive taxation is not very strong".

Progressive taxation has also been defended on the grounds of stability. It is claimed that the effects of economic shocks such as depressions are minimised under a progressive tax system, because taxpayers are shifted from one bracket to another (Blum and Kalven, 1953). During a recession, the wages of workers may have to be reduced, moving them into a lower tax bracket. In this new bracket, they are taxed at a lower marginal rate and are, therefore, able to retain more of their income - and this reduces the impact of the recession on their income. The opposite would occur during a boom and, as such, aggregate consumption will remain relatively constant despite macroeconomic shocks. Progressive taxation therefore acts as an automatic stabiliser in the economy.

The ability of progressive taxation to act as an automatic stabiliser is seen to be relatively unimportant, however. Blum and Kalven (1953: 34) note that it is "a part time case", applicable only in a recession - instead, the state can stimulate the economy by other, more effective means. Mishan and Dicks-Mireaux (1958) attempt to measure to what extent tax rates affect inflation. They conclude that "[b]uilt-in stability is built small into the 
system, not large" (Mishan and Dicks-Mireaux, 1958: 604), and the stabilising effects of a passive fiscal policy that maintains expenditure and progressive rate structure constant are found to be "disappointing". Thus other means of achieving stability may be more effective than progressive taxation and this argument is unconvincing.

The third argument for progressive taxation stems from the view that, since taxes impose a sacrifice on taxpayers, the state should ensure that the sacrifice is as small as possible (Carver, 1904). This so-called "sacrifice theory" leads to progressive taxation because the confiscation of one unit of income from a low-income earner entails a much greater sacrifice than the confiscation of the same unit of income from someone with a higher income (Edgeworth, 1897): therefore, if the state needs two units of income, it ought to confiscate both of these from the high-income earner. As progressive taxation achieves the goal of minimising sacrifice best, it ought to be implemented, according to this theory.

There are different variants of the sacrifice theory, distinguished by Fagan (1938); however, he notes that all of them make the same assumptions. Of these, the most important are that the marginal utility of money declines as income increases (Fagan, 1938) and that it is possible to measure sacrifices and to compare them for different taxpayers - "[t]o speak of aggregate sacrifice or satisfaction... implies that satisfactions are... capable of being summed" (Pigou, 1947: 41). Neither of these assumptions is unobjectionable.

The other assumption, that the marginal utility of money declines as income increases, has received considerable attention in the literature. Chapman (1913) provides a detailed theoretical critique of this assumption, explaining that is more realistic to hold that there are some points of discontinuity in the marginal utility of money curve. Cohen Stuart (1889) notes that, even if the marginal utility of money declines with income, this does not automatically entail progressive taxation. Instead, one needs to know what the precise shape of the utility of money curve is. Cohen Stuart's investigation shows that, while some declining utility curves justify progressive taxation, there are just as many other possible declining curves that justify proportional and even regressive taxation - in fact, progressive taxation is justified only if the utility curve is a rectangular hyperbola.

Some other theorists have attempted to derive the true shape of the utility curve mathematically, but their results have not been convincing. Pigou (1947) claims that it is impossible to determine the exact shape of the curve, while Preinreich (1948) notes that there are a number of difficulties associated with this problem and that all the practical attempts to solve it have, so far, been unsatisfactory. Harrod's (1930) investigation shows the curve to be steeper than a rectangular hyperbola, but Fagan (1938) questions the assumptions that he uses in arriving at this result. Thus it is by no means obvious that the curve is indeed declining, as is maintained by sacrifice theorists.

It has been shown that two of the key assumptions of sacrifice theory are dubious and controversial. Fagan (1938) lists several further assumptions of this theory and also calls them into question. The defence of progressive taxation on the grounds that it minimises disutility does therefore not appear to be convincing.

The final argument, that is, the one from equality, is probably the most satisfactory justification for progressive taxation. It stems from the view that economic differences between citizens need to be redressed by transferring wealth from the rich to the poor. This view is advanced by, among others, Marx and Engels (1848), Wagner (1883) and Lyons (1969) and it is claimed that progressive taxation is desirable because of its effectiveness in redistributing wealth - the wealthy are taxed at the highest marginal rates, and this tax revenue is then redistributed to the poor through government expenditure. Such an argument seems especially valid for a country like South Africa, with its history of racial discrimination and preferential treatment.

The main objection to this type of argument is that a progressive rate is unfair because it penalises some "people for having worked harder and saved more" than others and that it is, therefore, "a tax on industry and economy" (Mill, 1852: 371). There may, then, be no incentive to be productive or to save if marginal tax rates increase with income. Economic agents may decide to work less, master simpler trades and spend more time at leisure as a result of increasing marginal tax rates - this is detrimental to economic growth.

Rawls' (1971) “difference principle" summarises the issue well - he claims that a certain level of inequality is acceptable if society as a whole is better with these inequalities than it would be without them. Many of the arguments for the flat tax rest on this principle. While supporters of the flat tax accept that progressive taxation is 
the best system for achieving equality, they argue that everyone would be better off under a flat tax despite the inequalities. Aaberge, Colombino and Strøm (2004) liken the redistribution to the division of a cake, and, using their analogy, it may be that, although the progressive system would result in a more equal distribution of the slices, the cake itself would be bigger under a flat rate.

It seems, therefore, as though this is the most important argument for progressive taxation - that it is able to reduce inequalities through its redistributive characteristics. The supporter of a flat tax must, therefore, show that the other advantages of his system will outweigh the costs to equality. We will see how this may be done in the next subsection.

\subsection{Arguments For A Flat Tax}

The first type of argument for a flat tax is based on what may be called political responsibility. Blum and Kalven (1953: 19) point out that progressive taxation is irresponsible because "higher surtax rates are almost certain to apply only to a minority of voters". This means that the majority (low-income earners) are able to vote on and set the high tax rates that the minority pay. According to Blum and Kalven (1953: 19), this is unfair because "[n]o majority... can pass fairly or responsibly on an issue so infected with its own immediate self-interest."

A flat tax supporter, Armey (1996), summarises the arguments from political responsibility well. He claims that a flat tax is the fairest system because it treats everyone the same, avoiding the problem of having "fallible politicians decide, for their own reasons, which groups should render more or less of their earnings to the government" (Armey, 1996: 100). Instead, the flat tax does not discriminate between any economic group or agent, setting a single, objectively determined rate.

This kind of argument for a flat tax seems to have little force, however. As Blum and Kalven note, any system of majority rule will encounter this type of problem. There will always be those who disagree with a decision taken by the majority, and this is a logical and necessary consequence of a democracy, which is "superior to any other principle for resolving group decisions" (Blum and Kalven, 1953: 19). The advantages of a free and fair decision-making process will surely outweigh the relatively small disadvantage of the majority's "getting its own way". Besides, it may be said that the view of the majority best reflects the desires and wishes of the society and that there is nothing unfair in submitting to their suggestions.

A more convincing argument is that the flat tax is extremely simple compared with the progressive system. Advocates of a flat tax often claim that their tax return could be completed on a postcard (Hall and Rabushka, 1995; Forbes, 2005). This would save taxpayers hours of unproductive time spent completing complicated forms and finding ways in which to take advantage of tax loopholes (Blum and Kalven, 1953).

Studies have found that, although the majority of citizens regard progressive taxation as an inherently fair system (Porcano, 1984), few understand its complexity in practice (Roberts, Hite and Bradley, 1994). Edwards (2006) provides a detailed explanation of how a complicated tax system might impose costs on society - there are, among others, additional compliance costs in understanding the tax code and completing a complicated form; and there are also increased opportunities for tax evasion and avoidance if a tax system has many loopholes and deductions.

Several studies show that the administrative and compliance costs of a progressive system are indeed large in the United States (Slemrod and Sorum, 1984; Blumenthal and Slemrod 1992; Kaplow, 1994). The South African system also lends itself to abuse, as taxpayers can reduce tax liability by "taking advantage of loopholes in the Income Tax Act" (Jordaan, Boonzaier and Troost, 1988: 1). One strategy to reduce tax liability, which Gelfand (1958: 105) calls "fractioned income", exploits the weaknesses of the progressive system. In short, "fractioned income" involves one or both of two tactics: either "splitting income among related entities or deferring income to another period when the marginal tax rate is expected to be lower" (Gelfand, 1958: 105).

A proponent of a flat-rate tax system would argue that fractioning income is entirely due to the progressive nature of the current tax system. Under a flat system, all taxable units will be taxed equally, so no income-splitting 
would have to occur. Furthermore, there is no need to defer income to another financial year because all levels of income are taxed at the same flat rate. It is likely to be those citizens with the highest incomes who are best able to exploit the complexity of the tax system, as they are the ones who can afford to employ tax specialists.

Bankman and Griffith (1987) provide a detailed critique of these arguments and claim that they are flawed. One important point that they make is that deferral of income would probably occur under any tax system, because deferral provides benefits to individuals (and losses to the state) due to the time value of money. Although a progressive rate structure may increase the advantages of deferral, it is "valuable independent of the rate structure" (Bankman and Griffith, 1987: 1937). Thus the argument from simplicity, though quite powerful, is not indubitable.

The final argument for a flat tax is that it creates better economic incentives than a progressive system. Supporters of this view claim that progressive taxation provides disincentives to work and impediments to capital formation. This therefore reduces labour supply and inhibits production and economic growth. The flat tax, on the other hand, will not encounter these difficulties as each additional unit of income earned is subject to the same marginal tax rate as the others, thereby eliminating the disincentive to work. Blum and Kalven (1953) explain that these disincentives are typically caused by two factors.

The first such factor is that "a minority of the population" who are "likely to be of special importance economically" will be subject to disproportionately high taxes (Blum and Kalven, 1953: 21). In short, a progressive tax will curtail the production of precisely those individuals who are able to put capital to the best use, having the resources needed for productive investment opportunities.

The second factor that Blum and Kalven identify is that accelerating marginal tax rates will reduce work effort. This is because workers are likely to think in terms of costs and benefits when deciding how much time and effort to expend on their labour. With progressive taxation, the ratio of rewards to costs decreases with higher levels of income, so workers supply less labour than they would under a flat tax system.

This trade-off is studied in detail in Browning and Johnson (1984: 175), who find that "income redistribution is not a socially costless endeavour". They find that the costs of reducing income inequality through redistribution are "surprisingly high" (Browning and Johnson, 1984: 201), and note that their investigation considers only the effects of redistribution on labour supply, ignoring other possible costs such as the administrative and compliance costs discussed previously. Auerbach, Kotlikoff and Skinner (1981:2) find that even a small degree of progression "imposes a very large efficiency cost" in comparison with an equal-revenue proportional tax. Thus there may be an argument against progression in terms of inefficiency.

Several scholars have attempted to demonstrate the effect of progressive taxation on the labour supply. In an early study, Break (1957) interviews 306 solicitors and accountants in London, selected at random, asking them questions to determine to what extent progressive taxation affects their economic decisions. The results indicate that the progressive nature of the tax does not appear to play an important role in the respondents' decisions to supply labour.

This result is confirmed by several empirical studies. In a comprehensive survey of 21 studies that attempt to estimate the compensated elasticity of the labour supply, Bankman and Griffith (1987: 1923) find that these estimates "cluster around a reasonably narrow range". Most of the studies put the compensated elasticity of the labour supply for males, which Bankman and Griffith recognise as the main wage-earner group, between 0.1 and 0.3 . These figures imply that a $10 \%$ decline in wages because of a progressive income tax will be translated into a decrease in labour supply of between $1 \%$ and $3 \%$, which is relatively small. From this, Bankman and Griffith (1987: 1924) conclude that work is "conditioned more by social forces" than by wages - therefore, the predicted disincentive effect of progressive taxation does not appear to be large.

Later studies mirror these findings. Using a detailed econometric analysis, Triest (1990) reaches the conclusion that the labour supply of men is invariant to changes in tax rates. Moffitt and Wilhelm (1998) estimate the effect of the 1996 American Tax Reform Act, which significantly reduced marginal tax rates for the wealthy, on the labour supply of high-income men. They find that there is no responsiveness to this reduction. 
In his survey of the literature, Feldstein (1995) also states that the majority of earlier studies find that the working hours of men are not responsive to changes in tax rates. However, Feldstein adds the important warning that labour supply should not be seen as being identical with hours worked. Instead, "the amount of 'labo[u]r' that an individual supplies depends also on the intensity of work effort, the nature of the occupation, the assumption of risk and responsibility" and similar factors (Feldstein, 1995: 5).

Importantly, several of the studies show that the labour supply of women is responsive to changes in tax rates. Hausman and Ruud (1984) point out that, especially among married couples, labour supply behaviour is very different among women than among men. Bankman and Griffith (1987) find that twelve of the fourteen studies that they review estimate the compensated elasticity of labour supply of women above or near 1. Later studies by Triest (1990) and Feldstein (1995) confirm this result, though Triest claims that his conclusion depends critically on the method used to estimate the labour supply function.

Thus the disincentive effect of progressive taxation on the labour does not appear to be as large as expected. Other studies find that progressive taxation causes disincentives to save (Engen and Gale, 1997) or to become an entrepreneur (Cullen and Gordon, 2002). It may also lead to capital flight (Bakija and Slemrod, 2004; Kirchhof, 2005) to low-tax economies. However, it is essential to note that these disincentive effects may be the result of high tax rates, rather than progressive ones: a gradually progressive tax system with low rates might be preferable to a proportional system with one, high rate. The discussion of the arguments for and against a flat tax show, nevertheless, that this system should be given due attention as a policy alternative to the system of progressive taxation. This is the background and theoretical justification for the empirical analysis that is to follow in the next section.

\section{TAX REFORM AFTER DEMOCRACY}

Any analysis of the South African economy must note the important structural break that occurred in 1994, when the nation changed from a separatist state ruled by the minority to a true democracy. After the first democratic election, a new constitution was written and some of the tax changes reflect the non-discriminatory nature of the new South Africa. Specifically, all distinctions between genders and married or unmarried persons were removed as these were seen as discriminatory; thereby all natural persons became taxable according to the same progressive scale (Meyerowitz, 2003).

The Katz Commission was appointed to advise policy-makers on the tax structure of post-apartheid South Africa, and it released nine reports from 1994 to 1999 (Black et al, 2003). Improving tax administration and collection and reducing inequalities were the main goals of this commission, according to Black et al (2003), and several of its recommendations were introduced in the next few years.

Important changes resulting from the Katz Commission included the establishment of the South African Revenue Service (SARS) as an independent government department, the introduction of capital gains tax, taxes on interest and other income of the retirement fund industry and VAT on gambling and financial services, as well as the change from a source-based income tax to a residence-based one (Black et al, 2003). Furthermore, the number of brackets was reduced to six, with lower rates (Black et al, 2003). The more important changes will be discussed in greater detail in this section.

The granting of autonomy to the South African Revenue Service in 1997 indeed resulted in improved administration and tax collection (Manuel, 2002; Pama, 2004). According to Pama (2004), the years before 1994 saw an immense shortage of staff employed in tax agencies, with more staff employed at London's Heathrow airport alone than in the over 70 points of entry into South Africa. Collections were also burdensome, as each of the four former homelands (Ciskei, Transkei, Bophutatswana and Venda) had their own tax administration (Aaron and Slemrod, 1999).

However, since the independence of SARS, it has consistently been able to exceed estimated tax collections, which resulted in tax relief of about R73 billion and increased revenue of R57 billion in additional collections between 1995 and 2004 (Pama, 2004). This has led Trevor Manuel (2002: 4) to state that the Katz 
“Commission's recommendation of an autonomous SARS will be remembered as [its] most visionary contribution to the fiscal stabilisation effort."

One of the main challenges facing post-apartheid South Africa is reducing its tremendous degree of inequality, according to Aaron and Slemrod (1999). They point out that South Africa has one of the highest Gini coefficients in the world, and that any plausible tax system must address the problem of inequality. This challenge is recognised by the ANC, which seems to favour a policy of redistribution; however, some would argue that the inequalities are so great that they cannot be countered by redistribution alone and growth policies should take priority (Arnold, 1992).

Trevor Manuel (2002) points out that there have indeed been reforms that are geared towards economic growth, with the Secondary Tax on Companies ${ }^{1}$ being decreased from $25 \%$ to $12.5 \%$ in 1996 and the standard tax on businesses being reduced from 35\% to 30\% in 1999. These changes are in line with the view that investment should be stimulated through lower tax rates, rather than other "selective tax incentives" that could cause economic distortions (Manuel, 2002: 5).

Since the year 2000, the state has had the "distinct purpose of aggressively broadening the tax base" (Manuel, 2002: 5), thereby capturing more income in the tax net and reducing overall tax rates. The first basebroadening measure was the introduction of the tax on capital gains in 2001 (Manuel, 2002). Because it is usually the wealthy who are able to receive capital gains, this step is also redistributive in nature (Manuel, 2002).

Two further points about this tax are worth noting. Firstly, it was set at a competitive rate with generous exemptions (Manuel, 2002). This would prevent capital flight to lower-tax countries, which is considered by Aaron and Slemrod (1999) to be a threat menacing the new South Africa. Manuel (2002) notes that the taxation of capital gains is common practice worldwide, so it was plausible for South Africa to introduce it too.

Secondly, since tax advisors had previously spent unproductive time finding ways of reducing tax burdens by reclassifying income earned under normal means as non-taxable capital gains income (Manuel, 2002). Adopting a tax on capital gains would thereby reduce the incidence of tax avoidance through these means. Furthermore, there is the argument that gains from disposals of assets are "economic profits just like ordinary revenue", so that it is only fair to tax them as well if other income is taxed (Manuel, 2002: 5).

Shortly after capital gains tax was introduced, South Africa also changed its system from a source-based one to a residence-based one in 2001, thereby broadening the tax base even further (Manuel, 2002). Under the new system, South Africans are taxed on income earned overseas in addition to that earned within the borders of the country. Once again, this change means that the incentives for tax avoidance by earning income elsewhere disappear, resulting in reduced capital outflows. Furthermore, the tax also appears to be redistributive, as it is generally the wealthy who have the ability to earn income abroad.

Manuel (2002) notes several other important changes in the South African system. There have been reforms in the way South African owned foreign subsidiary companies are taxed, as well as the reduction of "harmful tax practices" such as tax incentives to attract foreign direct investment (Manuel, 2002: 8). Many public enterprises have been privatised, excise duties on soft drinks have been removed (Manuel, 2002) and it appears as though South Africans are beginning to develop a sense that it is important to pay taxes (Pama, 2004). The year 2007 has also seen an attempt by SARS to simplify the tax system further, using a redesigned tax form.

The changes to the South African tax system have been many. As Aaron and Slemrod (1999: 6) note, the Katz Commission undertook a sweeping reform of the country's tax structure, and its "reports reflect a tremendous amount of work". They also highlight some shortcomings of the commission, though, notably that there is little quantitative evidence to support its recommendations.

\footnotetext{
${ }^{1}$ The Secondary Tax on Companies is a tax on dividends paid out to shareholders, which is levied on companies in addition to the ordinary corporate
} $\operatorname{tax}$ 
A member of the Katz Commission, Judge Davis, also highlights some areas that still require reform (Surtees, 2001). He claims that, despite the commission's commitment to simplicity, the tax system has become more complex. The taxation of retirement funds also requires attention, because it is acting as a disincentive to invest; and other, non-tax incentives for investment ought to be created in order to grow the economy. Furthermore, the tax system could be made to be more competitive globally, and some new challenges facing the tax authorities are establishing common taxes for the African Union, policing tax havens and, in an effort to move with technology, creating tax systems for internet commerce (Surtees, 2001).

Vivian (2006) also criticises the Katz Commission, arguing that it has not achieved its goal of equality by demonstrating that its results are vastly different to those that would indicate equality as understood by the classical economists. However, the effects of the Katz Commission and the tax reforms of the 1990s appear to be more positive than negative, with a great deal of tax relief and improved simplicity, lower incidence of tax avoidance and more efficient revenue collection than ever before (Pama, 2004).

\section{CGE METHODOLOGY AND THE DATA}

The study compares the effects of a given shock (here a reduction in the value added tax (VAT)) on the South African economy when the flat tax or the progressive tax system is applied. A CGE model is used for this end. The CGE model in this study is calibrated from the 2003 social accounting matrix (SAM) provided by Quantec. The key characteristic of this SAM is that it distinguishes between 43 different production activities. Each activity is allowed to produce different commodities. There are 43 commodities in total. The government commodities and services are aggregated to one product class. The 2003 SAM also distinguishes between three different labour groups and capital as factors of production, as well as 14 different households. The household groups are divided into ten income categories with the upper deciles further divided into five different categories.

\subsection{The CGE Model}

The CGE model from which simulations were conducted in this study is mainly based on the model developed by Thurlow and Van Seventer (2002), which was adapted from a standard CGE model developed by Lofgren et al (2001) and the International Food Policy Research Institute (IFPRI). The model follows the neoclassical-structuralist approach and the set of equations are consistent with the SAM disaggregation of commodities, activities, factors and institutions as represented in the 2003 SAM.

As far as the modelling of different economic agents is concerned, the decision to maximise profit by producers is made with the choice between factors of production governed by a constant elasticity of substitution (CES). At the top level of activities, factors and intermediate inputs are combined using the Leontief specification. The constant elasticity of transformation (CET) function is used to represent the substitution possibilities between production of the domestic and the foreign market, hence differentiating between exported and domestic goods.

Furthermore, the model allows for substitution possibilities between imported and domestic goods under a CES Armington specification. As far as households are concerned, the model uses the linear expenditure system to capture the utility maximisation of households in consuming different commodities, given their incomes. The utility function is represented by the Stone-Geary function that allows for subsistence consumption expenditure. It is further assumed that commodities consumed by households and other economic agents are composite commodities constituted of domestically produced and imported commodities. Government receives income by imposing different types of taxes. The government expenditure is derived from the consumption of different commodities and from the transfer to households. Government saves if income is greater than expenditure and dissaves if the opposite occurs. All prices in the model are relative to a chosen numéraire. The consumer price index (CPI) is the chosen numéraire in the model, which makes the model purely real and as a result, the overall level of prices is not included in the model. While all parameters in this model are obtained by calibration from the 2003 SAM, all the elasticities are obtained from the CGE model of Thurlow and Van Seventer (2002). A static CGE is justified on the grounds that what we need in this study is to assess the performance of each of the tax systems on the areas of interest such as equity, economic growth and employment (mainly of unskilled labour). 


\subsection{Changes To The Standard Model}

The important change to the standard model occurs when modelling the effect of economic shocks on the South African economy when it is assumed that a fictional flat tax rate is applied. The introduction of the flat tax rate leads to direct tax rate becoming an exogenous rather than an endogenous variable in the model. Contrary to the model developed by IFPRI, that allows only the direct tax by institutions (personal and corporate taxes) to vary endogenously and therefore be the automatic source for financing many of the government spending programmes, this study transforms import tax from being a parameter or exogenous variable to becoming an endogenous variable in the government closure. With the balanced budget government closure used in this study, import tax rates are adjusted endogenously to generate a fixed level of government savings. An import tax scaling factor is then introduced in the model to scale the base-year import tax rate in order to clear the government balance. It is worth noting that this study constructs the revenue-neutral flat tax rate directly from the SAM. The average flat tax rate is obtained by dividing the sum of income tax paid by households by the total income of households.

As far as other closures are concerned for the factor market skilled labour, semi-skilled labour and capital are fully employed. Unskilled labours are partially unemployed. Investment-driven saving is used for investmentsaving closure as one of the objectives of the study consists in finding which tax reform would be capable of generating necessary private saving to finance the fixed real investment quantity. As far as the rest of the world closure is concerned, the free-floating exchange rate system in South Africa permits the rule of fixing foreign savings while allowing for a flexible exchange rate.

\section{THE COUNTERFACTUAL SITUATION}

The counterfactual situation whose effects will be tested in this model is a $10 \%$ decrease in the VAT rate, that is, from $14 \%$ to $12.6 \%$. We will compare the effect of this decrease for both the fictional flat tax and the current progressive tax system. This section will explain why the decrease in the VAT rate, in particular, was chosen for this simulation, as well as how it is modelled using the CGE technique.

The primary reason for cutting the VAT rate in this study is that it could be used to achieve the goals of the Accelerated and Shared Growth Initiative of South Africa (hereafter abbreviated as ASGISA) policy statement. ASGISA is a government policy that began in 2005, with the aim of achieving certain "ambitious public goals for growth and sharing of growth" (Presidency of South Africa, 2006). Its key aims are to reduce poverty and unemployment, to stimulate economic growth and to encourage investment, especially amongst small and medium enterprises (Presidency of South Africa, 2006).

It may be argued that a decrease in VAT could achieve some of the objectives of ASGISA. Firstly, a reduced VAT rate leaves consumers, who purchase products on which VAT in levied with more disposable income, thereby somewhat reducing poverty. Of course, it may be replied that the poorest of the poor do not pay any VAT at all, so that a reduced VAT rate would make no difference to their poverty. However, the VAT cut will nonetheless affect many consumers in South Africa positively, so it may be justified.

Secondly, it may be argued that much of the increased disposable income available to citizens will be saved. Higher savings rates mean that more money is available to be channelled into profitable investment projects through the banking system, thereby contributing toward the goal of increased investment.

Thirdly, one may claim that the decrease in VAT will raise the demand for goods on which VAT is levied. This increased demand may be translated into greater production by firms, which could require more labour, thereby reducing unemployment somewhat. The flat tax is also predicted to increase labour supply through incentive effects. Combining these two effects on the labour market with the possible increased investment that could take place means that GDP will increase through greater production. This achieves the goal of economic growth.

A further reason for cutting the VAT rate in this study is that it is deemed to be regressive by most economists. Reducing a regressive tax should be beneficial for poor households who already benefit from non-zero rated goods. Thus a decline in VAT should, ceteris paribus, bring about greater equity between citizens of a state. It 
is recalled that the flat tax has been criticised on equity grounds, and that the most successful theoretical argument for progressive taxation was found to be the argument that it brings about greater equality through redistributive effects than a flat tax does. Because the flat tax is therefore predicted to increase inequality, it is reasonable to adopt a policy measure that could, to a certain extent, counteract this effect while achieving the ASGISA goals.

One final question needs to be addressed - why has the decrease in VAT specifically been chosen to be $10 \%$ ? The answer is that a $10 \%$ reduction is both simple to model and reasonably small, so that not too much revenue is lost in indirect taxes to make this a serious shortcoming of the model. Obviously, the VAT rate could have been reduced by any other percentage, and it may well be a worthwhile study to investigate the effects of different VAT cuts on both tax systems. Once again, however, this exercise is left for further research.

Now that the choice of counterfactual situation has been elaborated and defended, it remains to discuss, briefly, how the CGE technique actually models the 10\% decline in VAT. It must be noted that the SAM used in this study does not have a specific item for VAT on its own. Instead, it has a variable called "commodity tax" that the study used as a suitable proxy for VAT. To model the decrease in VAT, we run a simulation where the commodity tax is set at $90 \%$ of its value in the benchmark model, for both the progressive system and for the flat tax.

\subsection{The Areas Of Interest}

When evaluating the results we need to be explicit about which indicators will be considered; that is, which of the hundreds of variables in the model are important for the purposes of this study. The study evaluates the results in line with some of the main objectives of the growth, employment and redistribution (GEAR) policy and its offspring ASGISA policy. These objectives are: increase in economic growth, employment and fair redistribution of income. The effects on the saving rate of households and investment share of total absorption or gross domestic expenditure (GDE), as contributors of economic growth, will also be evaluated.

The CGE model does not have the means to test whether or not a tax is simple, so this aspect of the debate cannot be considered here. Whether a tax system is to be recommended, however, can be assessed from its effect on certain variables. This is not a limitation of the model, therefore, since it is obvious that the flat tax, which requires only one calculation for tax liability, must necessarily be simpler than the complex progressive system by its very nature.

The equity aspect of the tax reform will be assessed through a constructed Gini coefficient. Following Creedy (2001), the coefficient is constructed using the following formula:

Gini Coefficien $t=1+\frac{1}{N}-\frac{2}{N^{2}} \sum_{i=1}^{N}(N+1-i) \frac{Y_{i}}{\bar{Y}}$

Where $N$ is the number of households

$Y$ is the household income arranged in ascending order

$\bar{Y}$ is the mean income of households

The Gini coefficient shows the degree of inequality in a frequency distribution such as personal incomes (Bannock, Baxter and Davis, 1998: 176). This coefficient can take a value between 0 and 1, where 0 represents perfect equality while 1 means absolute inequality. We would expect inequality to increase following the implementation of a flat tax, ceteris paribus, so the predicted result is a rise in the Gini coefficient.

Economic growth can be measured by the change in GDP. Since a flat tax is predicted to be growthinducing, we would expect the effect on GDP to be positive. Furthermore, the flat tax is purported to raise GDP through its incentive effects on the labour supply and on savings rates. The effect on saving may be measured by 
the change in the marginal propensity to save (hereafter abbreviated as the MPS). As we plan the change in the MPS, the saving-investment closure is investment-driven where in order to generate savings that equal the cost of investment the base-year savings rates of selected nongovernment institutions are multiplied by a scalar.

As for the effect on labour supply or employment, it must be remembered that the chosen macroclosure rule for this model assumes that there is full employment in the highly-skilled and skilled sectors of the economy, with all the unemployment occurring as unskilled labour. Thus the investigation will consider the effect of the changes on unskilled labour supply only, and the change is predicted to be positive.

Examining the effect on unskilled labour supply seems to be appropriate for the South African economy. The country is characterised by high levels of unemployment; which coexists with a shortage of skilled labour. Thus a model which assumes full employment in the skilled and highly-skilled sector while allowing for unemployment in the unskilled sector seems to be an adequate reflection of the current situation in South Africa.

The areas of interest that have been identified in this section may be summarised in Table 1 below. This table lists the various areas of interest together with the indicators that will be used to quantify them, as well as an indication of the predicted results for the two simulations.

Table 1: Predicted Results Of The Simulation

\begin{tabular}{|l|l|l|l|}
\hline \multirow{2}{*}{ Area Of Interest } & \multirow{2}{*}{ Indicator For Measurement } & \multicolumn{2}{c|}{ Predicted Direction Of Change } \\
\cline { 3 - 4 } & & \multicolumn{1}{c|}{ Progressive Tax } & Flat Tax \\
\hline Equality & Gini coefficient & Decrease & Increase \\
\hline Economic growth & Change in GDP & Small increase & Large increase \\
\hline Savings & MPS & Small increase & Large increase \\
\hline Incentive to work & $\begin{array}{l}\text { Change in labour supply } \\
\text { unskilled) }\end{array}$ & Small increase & Large increase \\
\hline $\begin{array}{l}\text { Investment share of total } \\
\text { absorption }\end{array}$ & Investment share of GDE & Small increase & \\
\hline
\end{tabular}

\section{RESULTS OF THE SIMULATION}

This section analyses the results of the CGE simulation. For each indicator, the results are presented in the form of a table, enabling a visual comparison between the effects of a cut in VAT on both tax systems. This is followed by an interpretation and evaluation of the results in each case.

\subsection{The Gini Coefficient}

The comparison of the Gini coefficients for a flat tax and the progressive system are shown in Table 2 below. It must be noted that the Gini coefficient of the benchmark economy is 0.609 .

Table 2: Comparison Of Gini Coefficients Of The Two Tax Systems

\begin{tabular}{|l|c|c|}
\hline \multicolumn{1}{|c|}{ Indicator } & Progressive Tax & Flat Tax \\
\hline Gini coefficient & 0.608 & 0.611 \\
\hline Percentage change in Gini coefficient & $-0.117 \%$ & $0.345 \%$ \\
\hline
\end{tabular}

From the second column in Table 2, the Gini coefficient dropped from 0.609 to 0.608 for the progressive tax system in the case of a $10 \%$ cut in the VAT rate. This is equivalent to a $0.117 \%$ decrease in the Gini coefficient. Therefore it seems as though a cut in the VAT rate will reduce inequalities in the South African economy as it is now, ceteris paribus. Economic theory supports this result. As far as the flat tax goes, Table 2 indicates that the Gini coefficient increased by $0.345 \%$ to 0.611 . This means that inequalities in the economy have become greater, and is also consistent with our predictions. The flat tax that has been modelled in this case applies to all incomes, thus the poor, who previously paid no tax, are now being taxed at the same rate as rich people. This should be translated by an increase in inequality. 
Furthermore, the introduction of the flat tax represents a significant tax cut for the high-income earners who were previously subject to a high marginal tax rate. For the highest income bracket, the marginal tax rate has declined from $40 \%$ to $11.1 \%$, which means that these people are better off financially than before. Thus, since the flat tax appears to benefit the wealthy and disadvantages the poor (at least in terms of tax liability), it must certainly increase the Gini coefficient. This result is therefore consistent with our expectations and backed by sound economic reasoning.

\subsection{The Change In GDP}

Table 3 shows the effects on GDP (measured in real prices) of the change in VAT on the two tax systems. Several other macroeconomic indicators are also presented in this table, listed in the first column. The second column shows what the values of these indicators were for the benchmark data set. Column three and five show the counterfactual equilibria for the progressive tax and the flat tax respectively. The percentage change from the benchmark to the counterfactual situation is given in the columns marked "(A)" and "(B)", where "(A)" refers to the change for the progressive tax and "(B)" to the change for the flat tax. Finally, the rightmost column shows the difference between the two systems, by subtracting the percentage change in the progressive system from that of the flat tax system.

Table 3: Comparison Of Changes In GDP Of The Two Tax Systems

\begin{tabular}{|l|c|c|c|c|c|c|}
\hline \multicolumn{1}{|c|}{ Indicator } & Base & $\begin{array}{c}\text { Progressive } \\
\text { Level }\end{array}$ & $\begin{array}{c}\text { \% Change } \\
\text { (A) }\end{array}$ & Flat Level & $\begin{array}{c}\text { \% Change } \\
\text { (B) }\end{array}$ & $\begin{array}{c}\text { Difference } \\
\text { (B - A) }\end{array}$ \\
\hline Gross domestic expenditure & 1230.999 & 1231.616 & $0.050 \%$ & 1233.744 & $0.223 \%$ & $0.173 \%$ \\
\hline Private consumption & 786.316 & 786.933 & $0.078 \%$ & 789.061 & $0.349 \%$ & $0.271 \%$ \\
\hline Government consumption & 239.053 & 239.053 & $0 \%$ & 239.053 & $0 \%$ & $0 \%$ \\
\hline Exports & 339.826 & 340.027 & $0.059 \%$ & 340.932 & $0.325 \%$ & $0.266 \%$ \\
\hline Imports & -319.357 & -319.558 & $0.063 \%$ & -320.463 & $0.346 \%$ & $0.283 \%$ \\
\hline GDP at market prices & 1251.468 & 1252.085 & $0.049 \%$ & 1254.213 & $0.219 \%$ & $0.17 \%$ \\
\hline GDP at factor cost & 1111.066 & 1111.366 & $0.027 \%$ & 1112.417 & $0.122 \%$ & $0.095 \%$ \\
\hline
\end{tabular}

The results of this simulation may be interpreted as follows: for a start, it is clear from Table 3 that a cut in the VAT rate will increase both gross domestic expenditure and household consumption for both the progressive tax system and the flat tax. This is likely to be due to the fact that consumers will demand more goods because of their reduced prices. These changes are conducive to economic growth.

Table 3 also indicates that the counterfactual situation will have no effect on government consumption. However, this is due to the macroclosure rules that have been chosen. We also note that both exports and imports will increase following the cut in the VAT rate. The values in Table 3 show that there is a negative change in imports, but it must be understood that the base is negative (at -319.357) as this represents money leaving the country. Therefore a negative change in the value of imports means that they have increased relative to the benchmark. Increased imports and exports imply greater economic activity, which is also indicative of economic growth. It must be noted that imports change more than exports for both tax systems $(0.063 \%$ and $0.346 \%$ against $0.059 \%$ and $0.325 \%$ ). This suggests that a depreciation of the rand is to be expected in the counterfactual situation, because relatively more is imported than exported after the policy change.

Table 3 also shows that GDP has increased in the counterfactual situation for both cases. This confirms the prediction that a decline in the VAT rate is growth-inducing, primarily through increased aggregate demand for goods and services, whose prices have been reduced.

Comparing the figures for the two tax systems leads to a valuable conclusion. In each case, the percentage change in the variables is significantly greater for the flat tax system than it is for the progressive system. For instance, the change in GDP at market prices is around 4.47 times greater for the flat tax than for the progressive tax $(0.219 \%$ as opposed to $0.049 \%)$. This seems to imply that there is indeed a significant growth benefit to adopting a flat tax - the rightmost column shows that the changes are dramatically greater for the flat tax than for the progressive tax in each case. 
These effects are likely to be attained because of the incentive effects that the flat tax will have on savings and the labour supply (all of which are supported from the results in the following subsections). The high-income earners, who benefit enormously from a cut in their tax rate, will use their additional disposable income for profitable investment opportunities, or save it to make it available to others. As such, the flat tax rewards risk-taking and entrepreneurship, because the successful entrepreneur is able to retain and re-invest a greater share of profits than before.

The conclusions that may be reached from the analysis of Table 3 are threefold: firstly, that the cut in the VAT rate will result in economic growth, ceteris paribus; secondly, that the growth effects will be much greater if this policy is implemented with a flat tax than with the current, progressive system; and thirdly, that this policy change is likely to cause a depreciation in the rand because it will increase imports relatively more than exports (to be discussed).

\subsection{The Savings Rate}

Table 4 below is a comparison of the changes in the marginal propensity to save under the two tax systems following the cut in the VAT rate. It is important to note that according to the investment-saving macroclosure used in this study the rates of saving (MPS) of selected institutions are multiplied by a scalar in order to generate saving that is equal to total investment. The performance of each tax system, in terms of savings and investment, is assessed with reference to the size of the scalar.

The table shows disaggregated data for households, where the first decile represents the poorest households and the $98^{\text {th }}$ to100th percentile represents the wealthiest households. The saving rate of enterprises is represented in the second row. It is shown from Table 4 that in the case of progressive tax system saving rates are multiplied by $0.164 \%$ in order to generate the level of saving that equals to the cost of investment bundle. The saving rate is higher for flat tax rate at $21.637 \%$. In addition to Table 4, Table 5 shows that the investment share of absorption is higher $(1.382 \%)$ in the case of flat tax than the progressive tax system $(0.618 \%)$.

Table 4: Comparison Of The Marginal Propensity To Save For The Two Tax Systems

\begin{tabular}{|l|c|c|}
\hline \multicolumn{1}{|c|}{ Indicator } & $\begin{array}{c}\text { \% Change } \\
\text { (Progressive) }\end{array}$ & $\begin{array}{c}\text { \% Change } \\
\text { (Flat) }\end{array}$ \\
\hline Enterprises & 0.164 & 21.637 \\
\hline Households - first decile & 0.164 & 21.637 \\
\hline Households - second decile & 0.164 & 21.637 \\
\hline Households - third decile & 0.164 & 21.637 \\
\hline Households - fourth decile & 0.164 & 21.637 \\
\hline Households - fifth decile & 0.164 & 21.637 \\
\hline Households - sixth decile & 0.164 & 21.637 \\
\hline Households - seventh decile & 0.164 & 21.637 \\
\hline Households - eighth decile & 0.164 & 21.637 \\
\hline Households - ninth decile & 0.164 & 21.637 \\
\hline Households $-90^{\text {th }}$ to $92^{\text {nd }}$ percentile & 0.164 & 21.637 \\
\hline Households $-92^{\text {nd }}$ to $94^{\text {th }}$ percentile & 0.164 & 21.637 \\
\hline Households $-94^{\text {th }}$ to $96^{\text {th }}$ percentile & 0.164 & 21.637 \\
\hline Households $-96^{\text {th }}$ to $98^{\text {th }}$ percentile & 0.164 & 21.637 \\
\hline Households $-98^{\text {th }}$ to $100^{\text {th }}$ percentile & 0.164 & 21.637 \\
\hline
\end{tabular}

Table 5: Comparison Of Investment Share Of Absorption Of The Two Tax Systems

\begin{tabular}{|c|c|c|c|}
\hline \multicolumn{1}{|c|}{ Indicator } & $\begin{array}{c}\text { Progressive Tax } \\
(\mathbf{A})\end{array}$ & $\begin{array}{c}\text { Flat Tax } \\
(\mathbf{B})\end{array}$ & $\begin{array}{c}\text { Difference } \\
(\mathbf{B}-\mathbf{A})\end{array}$ \\
\hline $\begin{array}{l}\text { Change in investment share } \\
\text { of absorption }(\%)\end{array}$ & $0.618 \%$ & $1.382 \%$ & $0.764 \%$ \\
\hline
\end{tabular}




\subsection{The Labour Supply}

Table 6 shows the likely effects of the $10 \%$ reduction in VAT on labour supply for the two tax systems. It must be recalled that this model assumes that there is unemployment only in the unskilled sector of the economy, and the table therefore shows only the predicted change in this sector.

Table 6: Comparison Of Changes In Labour Supply Of The Two Tax Systems

\begin{tabular}{|l|c|c|c|}
\hline \multicolumn{1}{|c|}{ Indicator } & $\begin{array}{c}\text { Progressive tax } \\
(\mathbf{A})\end{array}$ & $\begin{array}{c}\text { Flat tax } \\
(\mathbf{B})\end{array}$ & $\begin{array}{c}\text { Difference } \\
(\mathbf{B}-\mathbf{A})\end{array}$ \\
\hline $\begin{array}{l}\text { Change in unskilled labour } \\
\text { supply (\%) }\end{array}$ & $0.524 \%$ & $2.468 \%$ & $1.944 \%$ \\
\hline
\end{tabular}

The results show that the cut in the VAT rate will increase the supply of unskilled labour by $0.524 \%$ if the tax system is progressive and by $2.468 \%$ if a flat tax is in operation. This is certainly due to the increased demand for the outputs of production (see Table 3) - firms will demand more labour to meet this increased demand, and households will supply more labour in response.

Notably, however, the increase in labour supply is roughly five times as much for the flat tax as it is for the progressive tax. Thus there does seem to be a significant incentive effect associated with the flat tax - those who are content to be unemployed under a progressive system with high marginal rates may find it worth their while to work if a flat tax is in operation. This is consistent with our expectations and is based on sound economic theory. We may therefore conclude that a flat tax could be better at reducing unemployment through its incentives to work than progressive taxation, and this must be seen as an advantage of the flat tax.

\section{CONCLUSIONS}

By and large, the empirical investigation into the flat tax has yielded results that are consistent with economic theory. To summarise the findings of this paper, a scorecard for the two tax systems is provided in Table 6. The various economic objectives are listed on the left, and a tick is placed in the column of the tax system that seems to achieve these objectives most effectively. In the bottom row, the final score is shown for each tax system:

Table 7: Scorecard For The Two Systems

\begin{tabular}{|l|c|c|}
\hline \multicolumn{1}{|c|}{ Objective } & Progressive Tax & Flat Tax \\
\hline Equity & $\checkmark$ & $\times$ \\
\hline Effect on economic growth & $\times$ & $\checkmark$ \\
\hline Effect on savings & $\times$ & $\checkmark$ \\
\hline Effect on labour supply & $\times$ & $\checkmark$ \\
\hline Effect investment share of absorption & $\times$ & 4 \\
\hline Total score & 1 & $\checkmark$ \\
\hline
\end{tabular}

On the basis of some of the main objectives of the GEAR policy, it seems as though the flat tax has a slight edge over the progressive system, achieving four of the objectives more effectively than its opponent. However, the objective of equity may carry greater weight than the other objectives, especially in South Africa, and this might count decisively in favour of progressive taxation. What the empirical analysis does show, nevertheless, is that the flat tax indeed has enough advantages over progressive tax that it ought to be taken more seriously by policy makers than it has been in the past.

Further studies need to be done using flat tax systems that are constructed differently, perhaps using exemption levels for poor households to make the flat tax system more equitable. This investigation is merely a starting point for further research on the advantages and disadvantages of the flat tax system in South Africa. 


\section{AUTHOR INFORMATION}

Prof L. Bonga-Bonga, Ph.D., Faculty of Economic and Financial Sciences, Department of Economics and Econometrics, University of Johannesburg, South Africa, Head of Department, Associate Professor. Prof BongaBonga is reviewer and referee with the following International and national accredited journals: South African Journal of Economic and Management Sciences, African Finance Journal, South African Journal of Economic History, Economic Modeling, and Economic Research Southern Africa (ERSA). PhD in Economics, University of Johannesburg, Master in Economics, University of Pretoria, Bcom Honours in Economics, University of Pretoria, and Bcom Honours in Financial Management, University of Lubumbashi, Democratic Republic of Congo. Email: LBonga@uj.ac.za

Martin Perold, Department of Economics and Econometrics, University of Johannesburg, South Africa.

\section{REFERENCES}

1. Aaberge, R., Colombino, U. and Strøm, S. (2004). Do More Equal Slices Shrink the Cake? An Empirical Investigation of the Tax-Transfer Reform Proposals in Italy. Journal of Population Economics 17: 767-85.

2. Aaron, H. J. and Slemrod, J. (1999). The South African Tax System: A Nation in Microcosm. Tax Notes, December 6, 1999.

3. Armey, D. (1996). Why America Needs the Flat Tax. In: Hall, R. E., Rabushka, A., Armey, D., Eisner, R. and Stein, H. (eds). Fairness and Efficiency in the Flat Tax. Washington DC: The AEI Press. 96-101.

4. $\quad$ Arnold, M.W. (1992). Engaging South Africa after Apartheid. Foreign Policy, NO, 87 (Summer 1992): 139-56.

5. Auerbach, A. J., Kotlikoff, L. J. and Skinner, J. (1981). The Efficiency Gains from Dynamic Tax Reform. NBER Working Paper No. 819, National Bureau of Economic Research, December 1981.

6. Bakija, J. and Slemrod, J. (2004). Do the Rich Flee from High State Taxes? Evidence from Federal Estate Tax Returns. NBER Working Paper No.10645, National Bureau of Economic Research, July 2004.

7. Bankman, J. and Griffith, T. (1987). "Social Welfare and the Rate Structure: A New Look at Progressive Taxation.” In: California Law Review, Vol. 75, No. 6 (December 1987): 1905-67.

8. Bannock, G., Baxter, R. E., and DAVIS, E. (1998). The Economist Books: Dictionary of Economics. New York: John Wiley and Sons.

9. Black, P., Calitz, E., Steenekamp, T. and Associates (2003). Public Economics for South African Students, (2nd edition). Cape Town: Oxford.

10. Blum, W. J. and Kalven, H. Jr. (1953). The Uneasy Case for Progressive Taxation. Chicago: Chicago University Press.

11. Blumenthal, M. and Slemrod, J. (1992). The Compliance Cost of the U.S. Individual Tax System: A Second Look After Tax Reform. National Tax Journal, 45: 185-202.

12. Break, G. F. (1957). Income Taxes and Incentives to Work: An Empirical Study. The American Economic Review, 47: 529-49.

13. Browning, E. K. and Johnson, W. R. (1984). The Trade-Off Between Equality and Efficiency. The Journal of Political Economy, 92: 175-203.

14. Chapman, S. J. (1913). The Utility of Income and Progressive Taxation. The Economic Journal, Vol. 23, No. 89 (March 1913): 25-35.

15. Cohen-Stuart AJ (1889). On progressive taxation. Reprinted in: Classics in the theory of public finance. Musgrave RA, Peacock AT (eds) Macmillan, London, pp 48-71.

16. Creedy, Y.J. (2001). Taxation and Economic Behaviuor. Introductory Survey in Economics, volume 1. UK: Edward Elgar.

17. Cullen, J. B. and Gordon, R. H. (2002). Taxes and Entrepreneurial Activity: Theory and Evidence for the U.S. NBER Working Paper No. 9015, National Bureau of Economic Research, June 2002.

18. Edgeworth, F. Y. (1897). The Pure Theory of Taxation. The Economic Journal, 7: 550-571.

19. Edwards, C. (2006). Income Tax Rife with Complexity and Inefficiency. Cato Institute Tax and Budget Bulletin, No. 33, April 2006.

20. Engen, E. M. and GALE, W. G. (1997). Consumption Taxes and Saving: the Role of Uncertainty in Tax Reform. The American Economic Review, 87: 114-20.

21. Fagan, E. D. (1938). Recent and Contemporary Theories of Progressive Taxation. Journal of Political Economy, 46: 457-98. 
22. Feldstein, M. (1995). Behavioral Responses to Tax Rates: Evidence from TRA86. NBER Working Paper No. 5000, National Bureau of Economic Research, January 1995.

23. Forbes, S. (2005). Flat Tax Revolution: Using a Postcard to Abolish the IRS. Washington DC: Regnery Publishing Company.

24. Gelfand, J. E. (1958). The Avoidance of Federal Personal Income Taxes in the United States. The Journal of Finance, 13: 105-6.

25. Grecu, A. (2004). Flat Tax - The British Case. Publication of the Adam Smith Institute, London.

26. Hall, R. E. and Rabushka, A. (1995). The Flat Tax (2nd edition). Stanford: Hoover Institution Press.

27. Harrod, R. F. (1930). Progressive Taxation and Equal Sacrifice. Economic Journal, 40: 704-7.

28. Hausman, J. and Ruud, P. (1984). Family Labor Supply with Taxes. American Economic Review, 74: $242-8$.

29. Hobbes, T. (1651, this edition 1988). The Leviathan. New York: Prometheus Books.

30. Jordaan, J. H., Boonzaier, W. A. and Troost, E. (1988). Ways to Avoid Tax Legally. Cape Town: ABC Press.

31. Kaplow, L. (1994). Accuracy, Complexity and the Income Tax. NBER Working Paper No. 4631, National Bureau of Economic Research, January 1994.

32. Keen, M., Kim, Y. and VARSANO, R. (2006). The Flat Tax(es): Principles and Evidence. IMF Working Paper No. WP/06/218, International Monetary Fund, September 2006.

33. Lofgren, H., Harris, R. L. and ROBINSON, S. (2002). A Standard Computable General Equilibrium (CGE) Model in GAMS. Washington: International Food Policy Research Institute.

34. Lyons, D. (1969). The Ethics of Redistribution. Mind, New Series, Vol. 78: 427-32.

35. Marx, K. and ENGELS, F. (1848, this edition 2002). The Communist Manifesto (translated by Moore, S.). London: Penguin Books.

36. Manuel, T. (2002). The South African Tax Reform Experience Since 1994. Address at the Annual Conference of the International Bar Association, given on Thursday, 24 October 2002.

37. Meyerowitz, D. (2003). Meyerowitz on Income Tax. Cape Town: The Taxpayer.

38. Mill, J. S. (1852). Principles of Political Economy, (3rd edition), Vol. II. London: John W. Parker and Son.

39. Mill, J. S. (1863, this edition 1987). Utilitarianism. New York: Prometheus Books.

40. Mishan, E. J. and Dicks-Mireaux, L. A. (1958). Progressive Taxation in an Inflationary Economy. The American Economic Review, 48, No. 4: 590-606.

41. Moffitt, R. A. and Wilhelm, M. (1998). Taxation and the Labor Supply Decisions of the Affluent. Nber Working Paper No. 6621, National Bureau of Economic Research, June 1998.

42. Pama, A. (2004). A New Tax System for a New South Africa. International Tax Review, London, May 2004: 13.

43. Pigou, A. C. (1947). A Study in Public Finance (3rd revised edition). London: Macmillan and Co. Ltd.

44. Porcano, T. M. (1984). Distributive Justice and Tax Policy. The Accounting Review,. 59: 619-36.

45. Preinreich, G. A. D. (1948). Progressive Taxation and Proportionate Sacrifice. The American Economic Review, 38: 103-17.

46. Presidency Of South Africa. (2006). "Reflections on AsgiSA in its First Year." Report by the Presidency. Available online: www.thepresidency.gov.za/docs/asgisa.pdf. Accessed 24 August 2007.

47. Rawls, J. (1971). A Theory of Justice. Cambridge, MA: The Belknap Press of Harvard University Press.

48. Roberts, M. L., Hite, P. A. and Bradley, C. F. (1994). Understanding Attitudes Toward Progressive Taxation. Public Opinion Quarterly,. 58: 165-90.

49. Seligman, E. R. A. (1908). Progressive Taxation in Theory and Practice. American Economic Association Quarterly, 3rd Series, 9: 1-334.

50. Slemrod, J. and Sorum, N. (1984). The Compliance Cost of the U.S. Individual Tax System. NBER Working Paper No. 1401, National Bureau of Economic Research, July 1984.

51. Surtees, P. (2001). South Africa: Tax Reform Not Complete, But Pause Needed. International Financial Law Review, London edition, 20: 67.

52. Thurlow, J. and Van Seventer, D. (2002). A Standard Computable General Equilibrium Model for South Africa. TMD discussion paper No. 100. International Food Policy Research Institute. Washington DC.

53. Triest, R. K. (1990). The Effect of Income Taxation on Labour Supply in the United States. The Journal of Human Resources, Special Issue of Taxation and Labour Supply in Industrial Countries, 25: 491-516.

54. Vivian, R. W. (2006). Equality and Personal Income Tax - The Classical Economists and the Katz Commission. The South African Journal of Economics, 74:79-109.

55. Wagner, A. (1883). Three Extracts on Public Finance. (translated by Cooke, N.). In: Musgrave, R. A. and Peacock, A. T. (eds). (1958). Classics in the Theory of Public Finance. London: Macmillan. 1-15. 